\title{
$\begin{array}{lllllllll}\mathrm{I} & \mathrm{N} & \mathrm{S} & \mathrm{T} & \mathrm{I} & \mathrm{T} & \mathrm{U} & \mathrm{T} & \mathrm{E}\end{array}$
}

\section{The State of Working New Hampshire 2009}

\author{
A L L IS ON CHURILLA
}

$\mathrm{E}$ conomic forecasts predict that New Hampshire will fare better than other New England states during the economic downturn and recovery. ${ }^{1}$ Indeed, on many indicators through December 2008, the recent economic downturn has not been as hard on New Hampshire as it has been on other New England states. The state maintained the highest labor force participation rate (71 percent) and the lowest unemployment and underemployment rates of all six states in 2008 (4 percent and 8 percent, respectively). ${ }^{2}$

But comparisons to other New England states do not capture important economic changes that are affecting workers within the Granite State. Average wages in New Hampshire are at their lowest level since 2002. A rise in alternative work arrangements such as involuntary part-time work suggests that a growing share of workers are experiencing difficulty in finding full-time work that pays a livable wage. Claims for unemployment insurance have risen dramatically in recent years. This issue brief, produced in cooperation with the Economic Policy Institute (EPI), draws attention to these and other employment trends in the state.

\section{Economic Downturn Has Negative Impact on Wages}

In 2008, the median hourly wage in New Hampshire was $\$ 17.25$, representing a 5 percent increase since 2000. This modest increase over eight years conceals several years of wage stagnation and decline in the state. In the last year alone, the decline in the average worker's wages has counteracted even the modest wage gains accumulated since 2003. Figure 1 shows that New Hampshire workers' median wage was lower in 2008 than it was in any of the previous five years and only slightly higher than the median wage in 2002.

FIGURE 1. WAGE GROWTH FOR LOW-, MIDDLE-, AND HIGH-WAGE EARNERS IN

NEW HAMPSHIRE, 2000 TO 2008

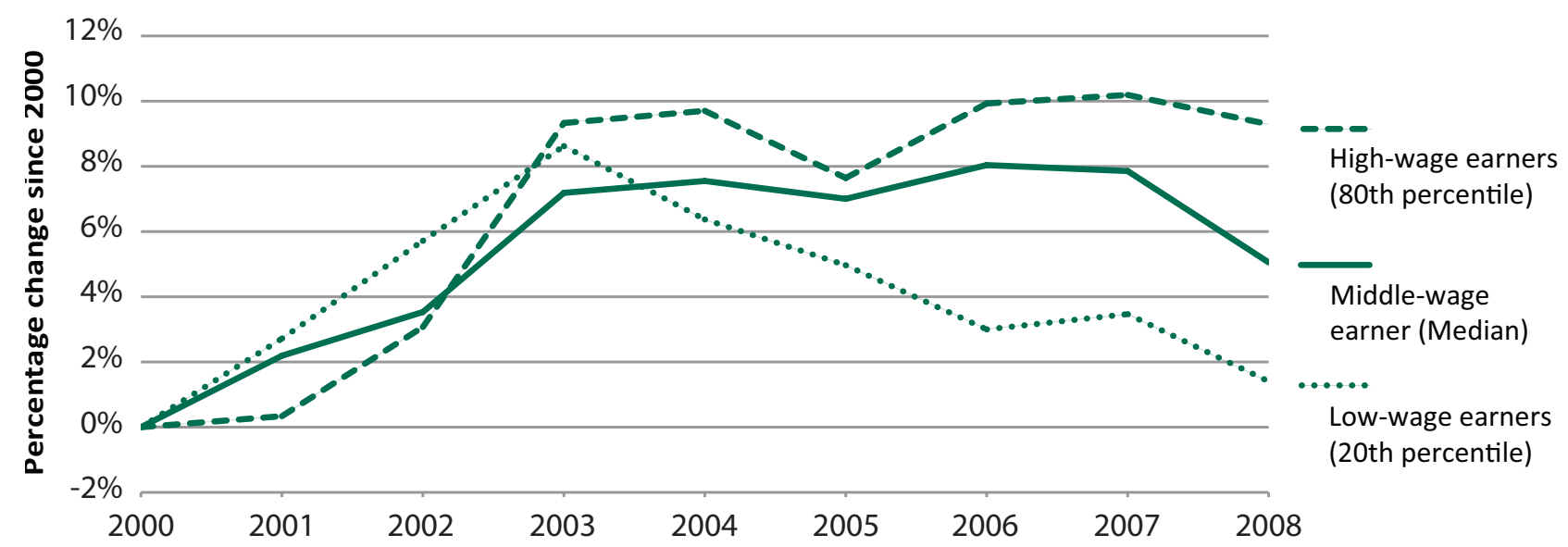

Source: Economic Policy Institute analysis of Current Employment Statistics survey data. 
Low-wage earners have been especially vulnerable: their hourly wages declined by 7 percent over the last five years. Even high-wage earners, who typically weather economic downturns better than other workers, have seen no overall increase in their wages since 2003.

\section{Growing Share of Workers Find Alternatives to Full-Time Work}

Wage stagnation is tied to changes in employment arrangements in recent years. Several indicators suggest that full-time work that pays a livable wage may be increasingly difficult to find in the state. Alternative work arrangements, such as holding multiple jobs and parttime work, have become necessary for a small but growing share of the labor force. In 2007, 7 percent of workers in the state held more than one job, one of the highest multiple job holder rates in New England. ${ }^{3}$ Since 2000, the share of New Hampshire workers who were employed part-time increased by over 1 percentage point (see Table 1). Importantly, increases in part-time work have been fueled by decreases in the share of workers employed fulltime and increases in the share of workers taking involuntary part-time employment.

In addition to changes in full-time employment, there are indications that a portion of New Hampshire workers are finding it increasingly difficult to find employment at all. The state unemployment rate has risen by 1 percentage point since 2000, prompting increases in the use of unemployment insurance. During a period in which the number of people employed in the state declined by 4 percent, initial unemployment insurance claims rose from
TABLE 1. EMPLOYMENT BY FULL-TIME AND PART-TIME STATUS, 2000 TO 2008

\begin{tabular}{c|c|c|c|c|c}
\hline Year & \multicolumn{3}{|c|}{ Percent part-time } & $\begin{array}{c}\text { Percent } \\
\text { full-time }\end{array}$ & Total \\
\hline & Total & Involuntary* & Voluntary & & \\
\cline { 2 - 4 } 2000 & 25.2 & 1.6 & 23.6 & 74.8 & 100.0 \\
2008 & 26.4 & 3.3 & 23.1 & 73.6 & 100.0 \\
\hline
\end{tabular}

Source: Economic Policy Institute analysis of Current Population Survey data.

* Those who give an economic reason for working part-time, including slack work, unfavorable business conditions, inability to find full-time work, and seasonal declines in demand.

29,500 in 2000 to 71,250 in 2008 , representing a 142 percent increase in initial claims. ${ }^{4}$ There is also evidence that workers are receiving unemployment insurance for longer periods of time, suggesting that labor market conditions have been impacted by the recent economic downturn.

\section{Amidst Overall Job Growth, Manufac- turing Jobs Continue to Disappear}

Despite changes in the employment status of New Hampshire workers in recent years, there has been positive overall growth in the number of jobs in the state since 2000 . The Granite State has experienced a net gain of 23,700 jobs, representing a 4 percent increase between 2000 and 2008. This outpaces job growth in all other New England states over the same eight-year time period.

Figure 2. AbSOLUTE AND PERCENTAGE CHANGE IN EMPLOYMENT BY INDUSTRY IN

NeW HAMpShire, 2000 TO 2008

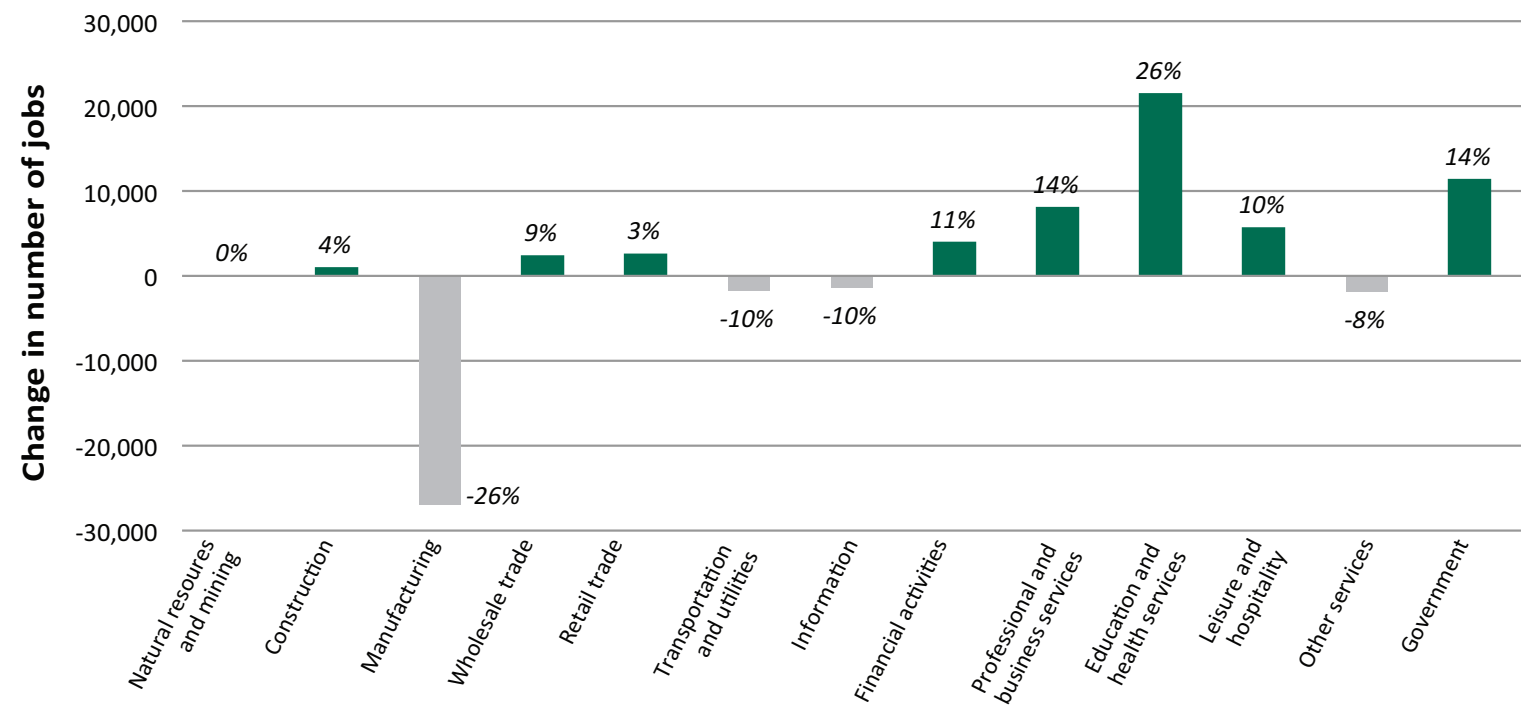

Source: Economic Policy Institute analysis of Current Employment Statistics survey data. 
Two-thirds of jobs in New Hampshire are in five industries that, for the most part, contribute positively to job growth in the state: education and health services, retail trade, government, manufacturing, and professional and business services. As indicated, four of these industries have experienced overall job growth since 2000; all of them are considered service-providing industries. The education and health services industry has contributed the most to this growth. Between 2000 and 2008, this industry added 21,400 jobs to the state, representing a 26 percent increase in jobs in this sector (see Figure 2).

The only goods-producing industry among the five largest industries in the state-manufacturing-is also the only industry among the top five in which jobs declined since 2008, and job losses in this industry have been considerable. The most marked decline occurred in the early 2000s, when the industry lost 22,100 jobs in the span of only three years. Although jobs in manufacturing have continued to disappear since 2003, the rate of job decline has slowed over the last five years (see Figure 3).

\section{Summary}

Relative to other states in New England, New Hampshire has fared relatively well during the recent economic downturn on several indicators of economic well-being. But for a sizeable portion of workers in the state, strained economic conditions have made it increasingly difficult to participate and thrive in the labor force. Although job growth is positive, full-time workers form a smaller share of the state's labor force, which now comprises of a growing share of involuntary part-time workers. For workers across the wage-earning spectrum, wages have largely declined or stagnated in recent years. These trends suggest that, although the state has fared better than its neighbors in recent years, New Hampshire workers are nonetheless feeling the effects of the economic contraction.

\section{DATA}

Unless otherwise noted, figures cited in this report are based on the Economic Policy Institute's analysis of Current Employment Statistics and Current Population Survey data. The Current Employment Statistics program surveys a sample of more than 400,000 business establishments and government agencies to provide industry estimates of job growth, hours, and wages. Data are collected as part of a joint effort between state employment security agencies and the Bureau of Labor Statistics. The Current Population Survey program surveys a nationally representative sample of 50,000 households and individuals in those households to provide demographic and employment information about the United States population. The survey is conducted by the U.S. Bureau of the Census for the Bureau of Labor Statistics. Except when noted otherwise, dollar amounts were adjusted for inflation to 2008 dollars.

\section{E N D N O T E S}

1. Ross Gittell, "Can We Afford the Future? The Fiscal and Economic Outlook for New England" (Walpole, MA: New England Economic Partnership, 2008), http://www. neepecon.org/slidesfall2008.htm, retrieved August 11, 2009.

2. Underemployed workers include those who are unemployed, employed as involuntary part-time workers, or mar-

Figure 3. JOB growth in NeW HAMPShire's five laRgEST INDUSTRIES, 2000 TO 2008

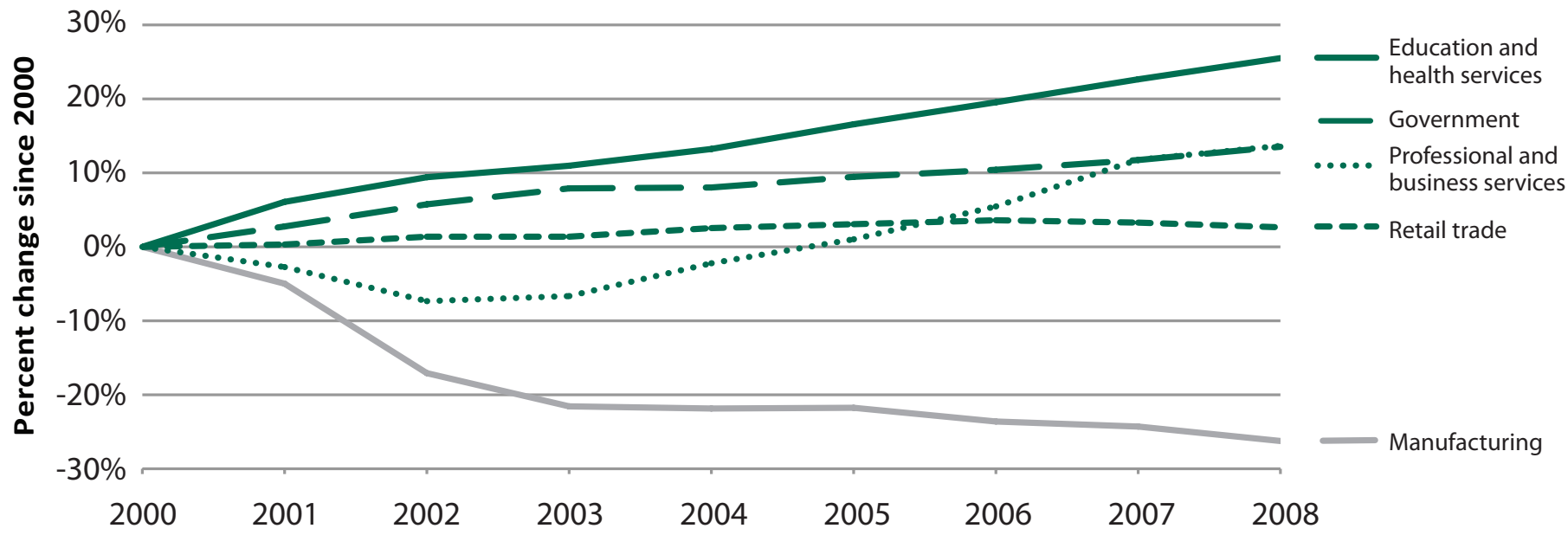

Source: Economic Policy Institute analysis of Current Employment Statistics survey data. 
ginally attached to the labor force. The marginally attached include those who want, are available for, and are looking for work but who had not looked for work in the most recent four weeks prior to data collection. These figures represent small changes in employment over the last eight years; based on these indicators, other states in New England have been less fortunate during the recent economic contraction. Rhode Island, for example, has not weathered the economic downturn as well, with unemployment hitting a high of 8 percent and underemployment at a high of 13 percent in 2008. See presentations from the New England Economic Partnership (http://www.neepecon.org/slidesfall2008.htm) for a detailed analysis of New England state economic projections.

3. U.S. Bureau of Labor Statistics New England Information Office, "New England and State Multiple Jobholders: 1996-2007" (Boston, MA: U.S. Bureau of Labor Statistics New England Information Office, 2008), http://www.bls.gov/ rol/nemjh.htm, retrieved August 11, 2009.

4. Author's analysis of data from the U.S. Bureau of Labor Statistics (http://www.bls.gov/schedule/archives/laus_ nr.htm) and the New Hampshire Department of Employment Security Economic and Labor Market Information Bureau (http://www.nh.gov/nhes/elmi/claims.htm).

\section{A U T H O R}

Allison Churilla is a graduate research assistant at the Carsey Institute and a Ph.D. candidate in the Department of Sociology at the University of New Hampshire (allison.churilla@unh.edu).

\section{A C K N OW L E D G M E N T S}

The author would like to thank Mil Duncan, Kristin Smith, Amy Sterndale, and Erin Trainer for their thoughtful comments on earlier versions of this brief.

\section{A UNIVERSITY}

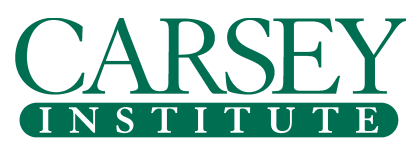

Building knowledge for families and communities

The Carsey Institute conducts policy research on vulnerable children, youth, and families and on sustainable community development. We give policy makers and practitioners timely, independent resources to effect change in their communities.

This work was supported by Jane's Trust and the Carsey Institute endowment.

Huddleston Hall

73 Main Street

Durham, NH 03824

(603) $862-2821$

www.carseyinstitute.unh.edu 